\title{
Integrative Model of Nussp Program Policy Implementation in the Poor Community Empowerment Based on Tridaya
}

\author{
Muhammad Tahir ${ }^{1}$, Yulianto Kadji ${ }^{2}$, Zuchri Abdussamad $^{2} \&$ Yanti Aneta $^{2}$ \\ ${ }^{1}$ Public Administration, Universitas Muhammadiyah Makassar, South Sulawesi, Indonesia \\ ${ }^{2}$ Public Administration, State University of Gorontalo, Gorontalo, Indonesia \\ Correspondence: Muhammad Tahir, Public Administration, Universitas Muhammadiyah Makassar, Makassar, \\ Indonesia. E-mail: muhtahir28@gmail.com
}

Received: July 3, 2017

Accepted: July 13, 2017

Online Published: August 23, 2017

doi:10.5539/res.v9n3p187

URL: http://doi.org/10.5539/res.v9n3p187

\begin{abstract}
The implementation of NUSSP (Neighborhood Upgrading Shelter Sector Project) program policy is a residential upgrading and settlement sector project in the context of urban slum settlement management for the empowerment of the poor communities based on tridaya in Makassar City which was implemented since 2005-2009 (phase I). This study used a qualitative approach by using case study at five urban villages of NUSSP's program locations as the key areas, namely: Buloa, Cambaya, Lette, Rappocini, and Balang Beru sub-districts within Makassar. The data collection used in-depth interview, Focus Group Discussion (FGD), direct and participatory observation supported by document study, case history, and triangulation. The results of this study indicated that the integrative model achievement of NUSSP's program policy implementation in handling of urban slum settlement by using the tridaya's empowerment approach as an effort to empower the poor society, in the form of output and outcome of policy implementation that had provided benefits for the government and the poor communities from the empowerment development aspect, such as the physical environment, economic empowerment, and social empowerment. Although from the economic aspect and social empowerment were not relatively optimal conducted by government and private parties, neither were not yet relatively optimal conducted by NUSSP executing actors in the utilization of local cultural values and religious values to support the successful implementation of NUSSP program policies in the field. The findings of this study were in the form of the development of "Tridaya" empowerment concept into "Pancadaya" (environmental, social, economic, cultural and religious development). This finding revealed that the importance of the use of cultural and religious values transformed in the poor community empowerment concept, so it was assumed that they will give a significant contribution in supporting the integrative model of NUSSP's program policy implementation in the handling of slums in order to empower the poor communities in urban slum areas.
\end{abstract}

Keywords: policy implementation, NUSSP program, slum settlement, Tridaya-Pancadaya empowerment, poor society

\section{Introduction}

The handling of urban slum settlements is a global development issue, which has been responded by the leaders of developing countries at a Millenniumhigh-level conference-the United Nations in 2000, which has agreed on the global development goals set forth in the Millennium Development Goals (MDGs) and one of its targets to improve the life quality of 100 million people in slums in 2020 (Menteri Pekerjaan Umum, 2008), thus obtaining funding support from international funding such as the Asian Development Bank (ADB). Therefore, ADB has worked with city governments and Non-Governmental Organizations (NGOs) in the developing countries to reduce poverty -slums- in Asia and the Pacific through joint efforts to promote pro-poor sustainable growth (Asian Development Bank, 2003). Furthermore, the Government of Indonesia has committed to implement a model of urban slum settlement policy program that receives ADB loan assistance through a residential and settlement improvement project as known as the "Upgrading Shelter Sector Project" hereinafter abbreviated as "NUSSP".

This NUSSP program's policy in its implementation is designed with the vision of the realization of competent local governments and communities and is able to create a healthy, viable and productive, self-sustainable living and residential environment. The NUSSP's general purpose is to assist governments in reducing/decreasing 
urban poverty through partnerships between governments, the private sector and communities. While NUSSP's objectives are focused on essential essences on the quality of residential and housing environments improvement for the poor society through the resources provision for local governments that work with communities and the private sector. The implementation principles that must be applied and agreed consistently by the actors in the NUSSP's implementation include: (1) Locations based on the Local Spatial Plan; (2) NUSSP serves only the poor society who live in the legal slum settlement; (3) Build without displacing; (4) Developing local potentials, i.e., developing the potential of existing resources in the community; (5) Encouraging awareness of the living environment; (6) Develop participation and integrity, involving all related actors independently, balanced and harmonious as well as establishing alignment with various parties.

Related to the Indonesian government's commitment, various urban slum settlement policy products have been implemented by the current central and local government, such as the "National Slum Development Movement" policy in 2001 and the "National Movement for One Million House Development (i.e., known as GNPSR in Indonesian acronym)" which began in 2004 and is planned until 2020, and the NUSSP's program policy in 2005. Therefore, it realizes a commitment and aspiration of Indonesia towards "Cities without Slums" in 2025 (Menteri Pekerjaan Umum, 2008).

Based on the shared awareness of the central and local governments that the handling of slum settlements, it is not enough to be solved physically, but it must be accompanied by community empowerment in order to establish the social capital to create an independent community that can solve the problem and build a decent, safe, healthy, harmonious and sustainable residential environment (Sudarpo et al., 2007).

Implementation of urban slum settlement policies conducted by the central and local governments has, for the most part, used a "from below" bottom-up approach that involves actors at the community level as implementers and employs an empowerment approach in the implementation of their programs. Through this approach, it can encourage societies to do their own policy implementation or keep involve government officials but only in the lowlands of the region. In this context, it is necessary to involve the intervention of public and private institutions in inter-organizational relations; So it needs to be designed in the mechanism of actors' cooperation network to ensure the functioning of coordination functions and in the inter-organizational or multi-agency setting, in order to achieve the implementation objectives of this urban slum settlement policy in the region (Pratikno et al., 2007). Hence, the actors' interaction must be established based on the basis of interdependence and running through the mechanism of resource exchange among actors as implementers.

Based on the integrative models of policy implementation (top down and bottom-up) in the handling of urban slum settlements, it is highly relevant to the integrative approach of "MSN" (mentality, systems and networking) model from Kadji (2015), which optimizes the role of all Implementation actors as the policy of stakeholders by utilizing cooperation networks of all stakeholders from government, private, and community, that will be more effective in implementing top-down and bottom-up public policies integrated in the handling of urban slum settlements based on poor community empowerment.

Based on the phenomenon of urban slum settlement policies implementation based on the poor community empowerment in Makassar city, which requires the integration of top-down and bottom-up policy implementation approaches; It is highly relevant to implement the NUSSP's program policy as an improvement and the quality improvement of urban slum neighborhoods known as "Neighborhood Upgrading Shelter Sector Project" (NUSSP). For the reason that the practice of implementing NUSSP's program policy in the empowerment of the tridaya-based poor community through urban slum settlement programs, at the same time has implemented two implementation approaches, i.e., top-down and bottom-up, involving NUSSP executing actors as implementing agencies by optimizingthe role cooperation network of all stakeholder as policy of stakeholders from government, private, and society.

One of the integrative policy products that have been reconstructed in solving various problems experienced by the poor community in the slum area of Makassar city is the NUSSP's program policy phase I in the handling of urban slum settlements based on the poor community empowerment which was implemented in Makassar City since 2005-2009. The implementation of the NUSSP's program policy is the embodiment of the spatial plan of Makassar city in 2005-2015 based on the Regional Regulation Number 6 in 2006, which confirms the utilization of slum-settlement areas within Makassar City; and efforts to realize the contents of Law No. 1 in 2011 on housing and settlement areas in Article 3 that its operation purpose is to ensure the establishment of affordable and affordable housing in a healthy, safe, harmonious, organized, planned, integrated, and sustainable environment; and the government needs to play a role in providing and giving facilities and assistance for 
housing and residential areas for the community through the provision of housing and settlement areas based on the region as well as community self-sufficiency, especially in slum areas of Makassar city.

One of the considerable challenges faced is related to the funding policies issue. This takes great effects because of the limited ability of central government funds through the state budget and local government through the budget of Makassar city in supporting the funding needs in handling urban slums in Makassar City. Moreover, the number of slums settlements to be handled is still highly considerable and also continues to grow every year.

It was recorded from 2005 to 2009 in the area of Makassar City which became the target of NUSSP phase I program, there were 11 districts and 42 sub-districts and slum areas that will be facilitated through NUSSP's program, i.e., approximately 440.94 ha. Particularly in five sub-districts of research location, slum areas as target of NUSSP program phase I (2005-2009) that would be handled in Buloa sub-district (714 ha) which is inhabited by poor family around 1,932 poor households; Balang Baru village (12 ha) is inhabited 1,466 poor families; Rappocini urban village (12 ha) is inhabited by 407 poor families; Cambaya village ( $4.70 \mathrm{ha}$ ) is inhabited 1,475 poor families; Lette urban village (3,46 ha) is inhabited 571 poor families (Korkot-3 NUSSP Makassar, 2011).

The implementation of NUSSP's phase I program policy based on the tridaya's empowerment, is an appropriate policy to solve funding problems in the handling of slum settlements in Makassar city, by using loan funds from the Asian Development Bank (ADB) through the Indonesian government (Central Government) to anticipate the limited of APBN's funds, as stated in the grant agreement on the use of grant funds based on Loan Agreement number 2072-INO dated on September 9, 2004 for the service of settlement environment project through NUSSP program; between the Government of the Republic of Indonesia (Central Government) and the Government of Makassar City Number: NPH-10/PB/2005, dated on June 7, 2005.

Based on the agreement on the use of grant funds from the Central Government, the Central Government's obligation of $60 \%$ (APBN) and the Government of Makassar provided 40\% companion fund (APBD), which has received support and approval from Makassar City Parliament.

The implementation of NUSSP's program policy phase I (2005-2009) in the handling of slum settlements in Makassar city had been supported by funding with a total budget of IDR 21,556,671,000, consisting of ADB loan funds (DIPA Loan 2072 INO) through APBN as much as IDR 12,348,594,000 (60\%) and 40\% sharing funds sourced from the APBD used amounting to IDR 9,055,690,000 (Dirjen Cipta Karya, 2009).

The implementation process of the NUSSP's program policy phase I (2005-2009) had been complemented by an ongoing cycle of gradual completion of the handling of slums settlements in Makassar, based on the community empowerment by using the "tridaya" approach; in order to generate three powers, namely: (1) the environmental development power; (2) social power; and (3) economic power (Krismanto et al., 2003).

The implementation of this "tridaya" empowerment approach in reality is not yet optimal in solving the economic and social crises problem, due to various constraint and obstacle factors faced in the field, which are more dominated by the mental attitude of NUSSP executing actors and the poor communities themselves as objects and subjects of NUSSP program. This condition occurs, because it is assumed to be one of the causal factors, which is not yet utilized religious values (Islamic religion) and local cultural values (Bugis-Makassar) which are majority of cultured and religious society, to be an empowerment's strategy in the formation of humanist and productive mental attitude for the poor communities. The relevant affirmed by Saharuddin (2009) states that the importance of laying the local cultural values in the poor community empowerment. Similarly, Suryadi's affirmation as cited in Matthoriq (2009) states that the importance of religious approach in the society empowerment through the intellectual and spirituality unity way.

\section{Theoretical Review}

\subsection{Integrative Model of Policy Implementation in the Perspective of Soren C. Winter Model}

An integrative model of policy implementation from Soren C. Winter (Parawangi, 2011) constructs an Integrated Implementation Model, which integrates top-down and bottom-up approaches, so that the various variables working on both approaches can be synergized in the research of policy implementation by focusing on behavioral approaches. Organizational and inter-organizational behavioral variables consist of commitment and coordination dimensions; Variables of lower-level bureaucratic behavior (street level bureaucratic behavior) with discretion dimension; Target group behavior has a positive and negative community response dimension in supporting or not supporting policy. The behaviors of this target group give the effect/impact to the policy and performance of lower level bureaucrats/apparatus.

Further, Winteras cited in Parawangi (2011) states that the policy implementation requires inter-organizational relationships to bring general policy changes into the implementation process that can be applied in many ways. 
Therefore, the process of organizational and intergovernmental policy implementation is characterized by commitment and coordination. In the implementation level, the commitment is intended as an agreement with the relevant agencies in maintaining the stability of the organization and network among existing organizations, in relation to the implementation of the program. It is intended to maintain the possibility of a sense of egoism among the implementing organizations of the program that may affect the outcome of an implementation. At the coordination level, the relationships pattern among organizations is very urgent and affects the determination of an implementation strategy. The setting up of a public policy can be implemented through two or more organizations, so the possibility to cooperate will typically be more complicated, this is where the importance of coordination is conducted between organizations.

Meanwhile, the lower level of bureaucratic behavioral variables in policy implementation are intended as the ability to implement and execute programs as important decisions using more dominant influences outside the formal authority (discretion). Therefore, the lower-level bureaucracy becomes an essential actor in the implementation of public policy, and its performance is consistent with the program standards relating to its activities. The target behavior variable of the target group in the implementation of public policy is a group of people, organizations or individual recipients who play a role not only in terms of policy impact, but also in influencing the implementation of the program through positive and negative actions. Hence, the implementation performance of the program is strongly influenced by the participant's characteristics, namely supporting or rejecting.

\subsection{Integrative Model of Policy Implementation in the Perspective of MSN-Approach Model}

A public policy that has been formulated and established into a policy product through a political process, then in the policy implementation in the field is an administrative process involving three public sectors concerned with public policy, namely: (1) government sector, (2) the private sector, and (3) the civil society sector. Referring to this, Kadji (2015) asserted that in the domain of good governance, there are three sectors (government, private, and civil society) as policy of stakeholders, in direct contact with public policy and governance, development, and society management. Kadji (2015) illustrates that the government in its existence both as the party maker and policy maker (policy actors), also the government as apparatus implementer or policy implementer. Meanwhile, the private sector is as a party with an interest in policy products that maintain the stability of economic and social life through the creation and provision of employment. The civil society is as a party that should realize that society is no longer just the object of a policy, but also as a subject of policy. In this case the involvement of the community in every stage of development policy, starting from planning, and implementation, supervision, and no less important is the involvement of the community in securing the results of development that is actually in contact with the public interest.

Further, Kadji (2015) asserted that in the policy implementation stage, it is necessary to synergize the role and existence of the three dimensions of policy of stakeholders, which can be realized and actualized through the mentality approach, system approach and net working method (or called as Policy Implementation Model through MSN-Approach) which is illustrated in Figure 1 below. 


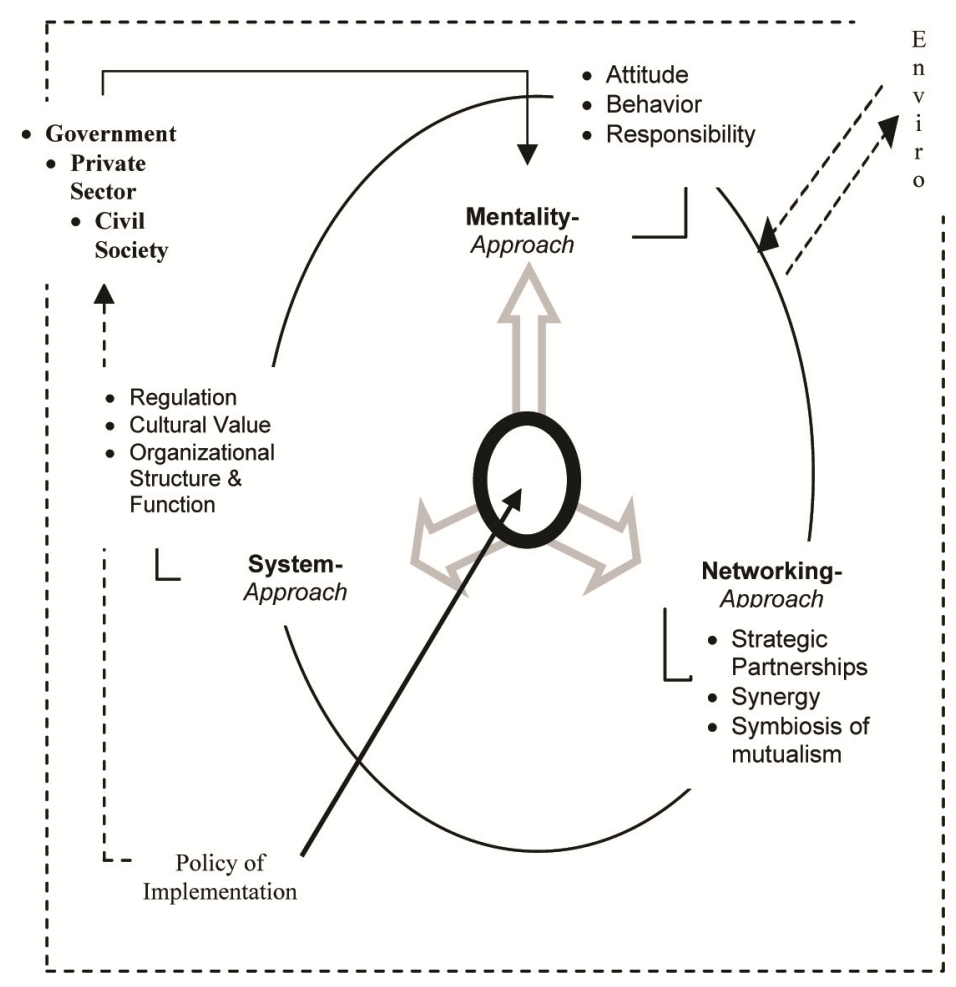

Figure 1. MSN-Approach Model in policy implementation (Kadji, 2015, p. 89)

Based on Figure 1 above, Kadji (2015) further confirms his proposition that a public policy will become actual and directed in implementation, if it uses or pays attention to at least what is called the MSN-Approach (Mentality, Systems, and Networking-Approach) or Mental, system, and cooperation network approach among government, private, and society. The policy implementation model through MSN-Approach (YK model) by using three integrative approaches, consist of: mentality, systems, and networking-approach. The integration of these three mental, system, and cooperative networks approaches between government, private, and community will be more effective in implementing integrated, top-down and bottom-up public policies.

One of the advantages of this MSN-approach model is its ability to explain the role of actors as policy implementers at the government and private levels (top-down) as well as at the bottom-up level, which is the policy of stakeholders. In this context, the MSN-approach model through a networking-approach with partnership, synergy and symbiotic mutualism indicators, attempts to illustrate the integration of "top-of-the-line" government policy implementation which is initiated by the government and private pareties, and the "from below" policy implementation which is initiated by the Community. Therefore, the implementation of public policy should prioritize the spirit of synergy and cooperation network among public policy stakeholders. This is particularly relevant to the affirmation of NUSSP's general manual (Sudarpo et al., 2006), the concept of NUSSP implementing organizations in the handling of urban slum settlements in Indonesia, involves three sectors as implementing agencies, government, private and community ideally having equal organizational capacity.

There is also another advantage of applying this MSN-approach model, through the mentality approach because it considers the mentality aspects of implementing public policy. The mentality approach emphasizes the attitudes, behaviors, and responsibilities of the policy implementers as policy of stakeholders, at the government level (central, city/district, sub-district, village/kelurahan); private level (businessman/business practitioners); as well as at the community level (individual or institutional).

The system approach aspect is another advantage of MSN-approach model, because it has been asserted that in practice of the public policy implementation is influenced directly or indirectly by a system covering the policy itself, in the form of bureaucratic, social, economic system, and local politics as well as a local-based education system. 
When it is examined theoretically and practically, the application of MSN-approach model is highly relevant to be used to analyze the implementation of urban slum settlement policies based on the poor community empowerment through NUSSP's program policy. It is well-founded that in practice the implementation of NUSSP's program policy in urban slum settlement needs to be analyzed by multi approach, i.e., mentality, systems, and networking approach or mentality, system, and cooperation network approach, so that the analysis results are more comprehensive and integrative.

\subsection{Tridaya's Empowerment Concept}

According to Krismanto et al. (2003), the Tridaya approach is essentially an approach that emphasizes the process of "true" empowerment to support sustainable development, i.e., the empowerment of the whole person in order to be able to generate the "three power" that are possessed by the human, namely: (1) social power in order to create socially effective societies, (2) economic power to create an economically productive society, and (3) the environmental development power in order to create a society concerned with sustainable environment development. The concept of the "Tridaya" approach can be illustrated in Figure 2 below.

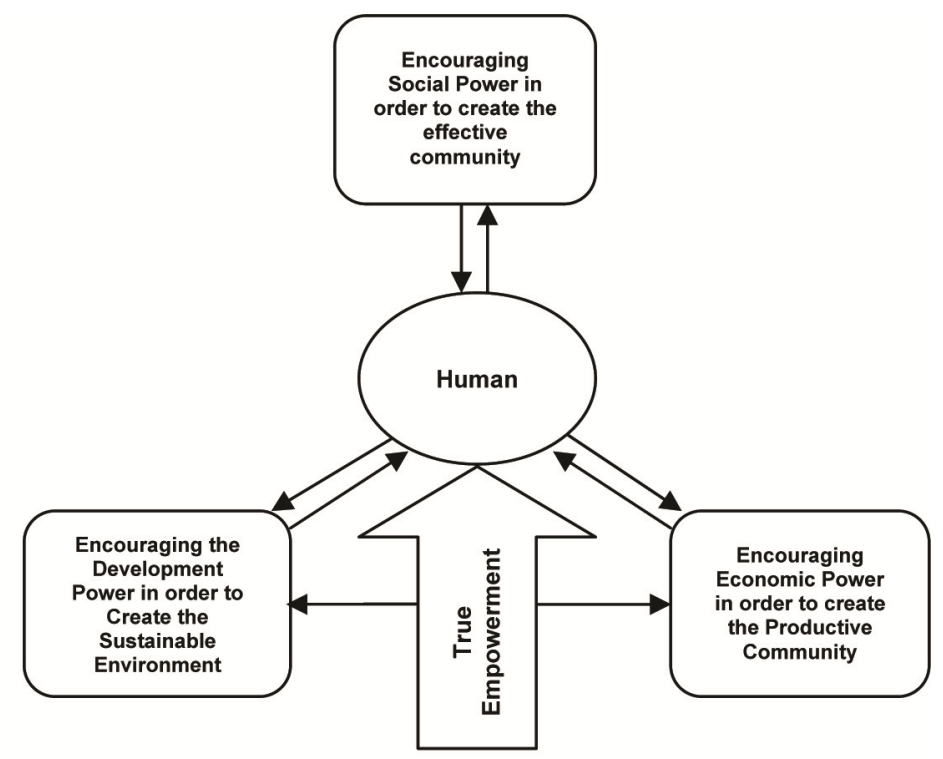

Figure 2. Tridaya Approach (Krismanto, 2003)

The targets of the Tridaya approach are: (1) increasing individual, family, environmental and community awareness to be responsible for the quality improvement of the slum neighborhood, its operational and maintenance activities; (2) increasing awareness of local governments in order to create the closer relationship with communities and their environment; (3) increasing the effectiveness of financing activities; (4) realization of mobilization of community capital; and (5) the realization of community systems and structures that reflect local conditions rather than uniform patterns between communities.

\subsection{The Community Empowerment Concept in Cultural Perspective}

Referring to the discussion of the community empowerment theories and approaches is closely related to the views of communitarian theory. According to Glen as cited in Parsons (2006), "one of the main approaches in the community is Community development which is an approach that seeks to help communities to encourage themselves. It refers to the community empowerment through a community approach that possesses the local wisdom values". Saharuddin (2009) states that "the empowerment of local wisdom-based society is interpreted as the placement of local values as an input for poverty alleviation, which is an appreciation of poverty reduction practices initiated by local actors by making national policies as development signs of the strategic cooperation in various sectors in poverty alleviation". In this context, the local wisdom as a cultural value of a local community becomes very important to be adopted in the poor community empowerment.

A poor community which has the local wisdom can be a strategy that emerges within the society itself in improving social problems concerning the lives of the poor communities themselves. The local wisdom is the result of interaction between society and its environment, so it is necessary to help society independently. 
Therefore, local wisdom as a local cultural value of local community becomes the core of the effort to overcome the existing poverty and grow in the community as the target of the process of implementing poverty alleviation program (Saharuddin, 2009).

According to Geertz (1992) as cited in Syarif et al. (2016), "culture is built from the regional culture that grows and develops in every ethnicity". Similarly, the characteristics of the Bugis-Makassar cultural values are the two ethnicities of the four major ethnic groups (Bugis, Makassar, Mandar, Toraja) residing in South Sulawesi.

\subsection{The Community Empowerment Concept in Religious Perspective}

Based on the Islamic development perspective in relation to the community empowerment, Al Buraey (1986) as cited in Matthoriq (2009) concludes that "the Islamic development perspective, whether socio-economic, political, administrative or cultural dimension is a comprehensive and integrated system which addresses itself to all human personality issues (existence), whether physical or spiritual. Islam strongly emphasizes to balance between them. Certainly, the application in social life is the growth of the spirit in order to prosper themselves and others".

A poor community empowerment through a religious (Islamic) approach is to protect a weak society in the empowerment process so that it does not become weakened by its lack of empowerment in the face of the strong party. This community empowerment shows the actualization of Islamic values through strengthening within the scope and important sectors of society. The integrity of empowerment on the individual, family and community; towards the material prosperous and have a high spiritual quality/civil society through the order of life consisting of social community which is interacted civilized, personal piety and social piety.

This is relevant to that proposed by Efendi (2007), there is an approach of three societies empowerment which mentions the existence of empowerment of the spiritual dimension, intellectual dimension and economic dimension; the three of them are very urgent to be prioritized in the society context nowadays. Meanwhile, Suryadi (as cited in Matthoriq, 2009) asserts that community empowerment in an applied context is a developmental approach to develop a society towards the real civil society through a true religious path, it is urgent to avoid materialistic and empirical traps without the unity between intellectual and spirituality.

According to Istiqomah in Matthoriq (2009), the existence of several principles in empowering people based on Islamic values, include: (1) Efforts of community empowerment can be seen as laying of a social order in which human beings fairly and openly can do business as a manifestation of the ability and potential so that their needs (material and spiritual) can be fulfilled; (2) Community empowerment should be consider as a learning process to the societies so that they can independently make efforts to improve their life quality; and (3) Community empowerment is an effort of community involvement in a development program when society itself does not have power.

Based on the religion (Islamic) perspective, the community empowerment in essence does not make the community become more dependent on various donation (charity) programs, because basically every what is enjoyed should be produced based on their own, and the results can be exchanged with other parties. However, for the poor people, who are unable to help themselves, need to be empowered through the provision of relief and income support provided by the government and social organizations as well as zakat, wakaf, alms and the provision of funds through the maximum budget.

\section{Method}

This study used qualitative approach by applying case study. The research location was at the five urban villages, namely: Buloa, Cambaya, Lette, Rappocini and Balang Baru in Makassar city. The data sources from key informants included governments, private, local social institutions, community leaders, religious leaders and poor societies, which were determined purposively in the early stages. In the field development, it was conducted by snowball sampling until obtained complete data and information and showed the saturation level. The research instrument was the researchers themselves who used several supporting measurements which included: (1) Interview guides, (2) Guidelines for focused observation, (3) FGD's Guidelines, (4) Secondary data collection format, and (5) Document notes. The data collection techniques included: in-depth interviews technique, conducting FGD, participatory observation, and documents. This qualitative research data analysis was conducted interactively and continuously until it was complete through several steps systematically, i.e., data collection/recording, data reduction, data display, verification and drawing conclusion.

\section{Research Results}

Implementation of slum settlement program policies through the NUSSP (2005-2009) program in the slum areas of Makassar city has provided benefits for Makassar city government, especially the local urban village 
administration which covers 42 sub-districts spread in eleven sub-districts, especially in five administrative villages (i.e., known also in Indonesian language as Kelurahan) of the research location. The benefits value that is most affected directly by the village government as the target location of NUSSP program is the creation of slum neighborhoods that had the infrastructure paths and roads along with the drainage environment, so the environment becomes neat, clean, and beautiful, after the infrastructure development conducted through NUSSP activities in the administrative villages program target.

The total number of NUSSP activity packages as the output of program implementation in NUSSP construction of paving block and drainage road infrastructure in 42 sub-districts is spread in eleven sub-districts in the slums settlements of Makassar city, it can be seen from the data in Table 1.

Table 1. Condition of NUSSP's financing and Activity Packages (2005-2008)

\begin{tabular}{cccccc}
\hline Description & Fiscal in 2005 & Fiscal in 2006 & Fiscal in 2007 & Fiscal in 2008 & Total \\
\hline Package Total & 12 SP3's Packages & 49 SP3's Packages & 44 SP3's Packages & 43 SP3's Packages & 145 SP3 \\
Real Cost Value (IDR) & $2,363,900,000$ & $7,566,539,000$ & $6,485,068,700$ & $6,470,434,000$ & $22,885,941,700$ \\
\hline
\end{tabular}

Source: Kantor Korkot-3 NUSSP Kota Makassar, 2011.

Note. SP3 (i.e., the Indonesian abbreviation of Surat Perintah Pelaksanaan Pekerjaan—Work Order Implementation Letter).

If we look at Table 1 above, it can be seen that the implementation of physical infrastructure development and improvement of the quality of settlement environment in Makassar city areas, which are realized in the form of construction of paving block road (walkway and neighborhood road, i.e., 207,702 meters), drainage (24,181 m), water supply (6 units of public hydrant), environmental sanitation (public toilets/communal septic tank (46 units)), and communal garbage (443 units). So the total consists of 145 packages in accordance with the warrant for the work implementation (SP3) submitted to the BKM (i.e., Indonesian acronym of Community Self-Reliance Agency) with the total cost is IDR 22,885,941,700.

From the total absorption of funds sourced from the State Budget (APBN)/Asian Development Bank (ADB) and Local Budget (APBD) and community self-financing have been utilized to build a slum neighborhood infrastructure in Makassar city, i.e., in the form of output of the road physical construction activities consisting of walkways and roads and opened drainage and drainage of plat duicker, environmental sanitation, waste equipment procurement, and clean water supply, as the data are presented in Table 2.

Table 2. Output results of NUSSP's infrastructure development activities in Makassar city (in 2005-2009)

\begin{tabular}{cccc}
\hline \multirow{2}{*}{ No } & Type of Physical Development Program & \multicolumn{1}{c}{ Realization of NUSSP Programs/Activities } \\
\cline { 3 - 4 } A & Connecting Road & Type of Activities & Total \\
\hline B & Drainage & 1. Walkway & $32.280,41 \mathrm{M}^{3}$ \\
C & Environment Sanitation & 2. Neighborhood Road & $31.989,03 \mathrm{M}^{3}$ \\
D & Procurement of Waste Equipments & 4. Plat Duicker & $294,49 \mathrm{M}^{3}$ \\
E & Clean Water Supply & 5. MCK (Communal Septic tank) & 48 Units \\
\hline
\end{tabular}

Source: Data Analysis Results ofthe Final Report of Korkot-3 NUSSP Makassar, 2011.

The economic benefits gained by the poor community after the implementation of the NUSSP program policy after the construction of paving block and drainage infrastructure in slum settlement areas, followed by economic empowerment have had an impact on the increase of income of the poor society in the administrative villages of this study location. This can be seen from the data presented in Table 3 below. 
Table 3. Economic benefits of results sales improvement for various types of small and medium enterprises of poor society at pre and post NUSSP infrastructure development

\begin{tabular}{clll}
\hline \multirow{2}{*}{ No } & \multicolumn{2}{c}{ Types of Business/Services } & \multicolumn{2}{c}{ Revenue/Profit Improvement } \\
\cline { 3 - 4 } & & \multicolumn{1}{c}{ Pre Development } & Post Development \\
\hline 1 & Housing contract value & IDR 600,000-800,000/year & IDR 3,000,000-6,000,000/year \\
2 & Selling fried banana & IDR 90,0000/day & IDR 180,000/day \\
3 & Food/Coffee stall & IDR 200,000/day & IDR 300,000/day \\
4 & Selling mixed goods & IDR 400,000/day & IDR 500,000/day \\
5 & Selling mixed goods/traditional cake & IDR 100,000-150,000/day & IDR 200,000-300,000/day \\
6 & Selling nasikuning & IDR 50,000/day & IDR 70,000/day \\
7 & Selling mixed goods/vegetables & IDR 200,000/day & IDR 300,000-500,000/day \\
\hline
\end{tabular}

Source: Primary Data Results Analysis (FGD/Interview) of the Poor Society.

The data presented in Table 3 above shows that there is an average increase of $68 \%$ of sales from each type of informal sector business (selling mixture, selling traditional cakes, selling food, selling vegetables, coffee shops, rented house rent) which are conducted by the poor societies after the construction of paving block and drainage road infrastructure and after the implementation of the NUSSP program in the slum settlement areas. In addition, it is economically an increase in area/land prices after the construction of road infrastructure and drainage through the NUSSP program/activity, depending on the extent of the building, and whether the location is strategic not. The data are presented in Table 4.

Table 4. Increasing of area/land prices for pre and post NUSSP's infrastructure development in five administrative villages of research location

\begin{tabular}{|c|c|c|c|c|c|}
\hline \multirow{2}{*}{ No } & \multirow{2}{*}{$\begin{array}{l}\text { Administrative } \\
\text { Villages }\end{array}$} & \multirow{2}{*}{$\begin{array}{l}\text { Large of Area } \\
\text { Location }\end{array}$} & \multicolumn{2}{|c|}{ Increasing of Area/Land Prices (IDR) } & \multirow{2}{*}{$\begin{array}{c}\text { Increase } \\
(\%)\end{array}$} \\
\hline & & & Pre-Development & Post-Development & \\
\hline 1 & Buloa & $10 \times 15 \mathrm{~m}^{2}$ & $2,500,000$ & $20,000,000$ & $800 \%$ \\
\hline \multirow{2}{*}{2} & \multirow{2}{*}{ Cambaya } & $10 \times 15 \mathrm{~m}^{2}$ & $20,000,000$ & $40,000,000$ & $200 \%$ \\
\hline & & $10 \times 15 \mathrm{~m}^{2}$ & $20,000,000$ & $100,000,000$ & $500 \%$ \\
\hline \multirow[t]{2}{*}{3} & Rappocini & $10 \times 15 \mathrm{~m}^{2}$ & $80,000,000$ & $200,000,000$ & $250 \%$ \\
\hline & & & $18,000,000$ & $50,000,000$ & $278 \%$ \\
\hline \multirow[t]{3}{*}{4} & Le tte & $10 \times 15 \mathrm{~m}^{2}$ & $20,000,000$ & $150,000,000$ & $650 \%$ \\
\hline & & & $20,000,000$ & $200,000,000$ & $1,000 \%$ \\
\hline & & & $5,000,000$ & $50,000,000$ & $1,000 \%$ \\
\hline \multirow[t]{2}{*}{5} & Balang Baru & $10 \times 15 \mathrm{~m}^{2}$ & $15,000,000$ & $50,000,000$ & $333 \%$ \\
\hline & & & $70,000,000$ & $150,000,000$ & $214 \%$ \\
\hline
\end{tabular}

Source: Data Analysis Results of Interview and Field Observation, August 2013.

In slum settlement areas before (pre) development of road and environmental infrastructure of the paving block still looks heavy slum causing area/land plot prices along with buildings on it has a low economic value. However, after (post) the development of road infrastructure in the paving block accompanied by the construction of the drainage, it causes a significant improvement in economic value to the area/land prices, until it reaches a price between 20 million rupiah to 200 million rupiah. This phenomenon becomes the interest of the capital investors/owners to the magnitude owned by urban slum neighborhoods, especially in five administrative village of the study location which were targeted by NUSSP program/activity, after the construction of the road and environmental infrastructure in the paving block accompanied by the development of drainage, then the capital investors/owners were interested to buy the area/land plots locations that are hectare wide to be used as warehousing areas, offices, housing, and/or only be as an investment. 
When it is reviewed from the social aspect, the various benefits that have been obtained by the community, such as the development and strengthening of the community capacity are focused on the aspects of local institutions, social groups, and community participation. For more details, it can be seen from the achievement results of the community institutional capacity strengthening in Table 5.

Table 5. Achievement results of the community institutional strengthening in NUSSP program implementation in 2005-2008 fiscal years

\begin{tabular}{clcc}
\hline No & \multicolumn{1}{c}{ Capacity Strengthening Results } & Unit & Volume(Person/Group) \\
\hline A. & Local Institution & Institution & 42 \\
1. & Total of established BKM & Person & 357 \\
2. & Total of BKM's Collective Leaders & Person & 85 \\
3. & Total of BKM's Women Collective Leaders & Person & 350 \\
4. & Total of Implementer Unit Members of BKM & & \\
& (UPL, UPK, UPS) & Person & 78 \\
5. & Total of Implementer Unit Women members & & \\
B. & of BKM (UPL, UPK, UPS) & & 55 \\
1. & Tommunity Social Group (CSG) & Group & 283 \\
2. & Total of Group Members & Person & \\
\hline
\end{tabular}

Source: Directorate General of Human Settlements Ministry of Public Works in Establishing of Hopefully Pillar, 2010.

On the other hand, the community participation level involved in the implementation process of the NUSSP program policies which was implemented through various stages of forming activities as volunteers as the community mobilize (i.e., known as TPM), program socialization and participation in the NUSSP program implementation cycle and involved in training/coaching can be shown in Table 6 below.

Table 6. Achievement results of community participation level in NUSSP's program/activity implementation in 2005-2008 fiscal years at Makassar City

\begin{tabular}{clcc}
\hline No & \multicolumn{1}{c}{ Community Participation Achievement Results } & Unit & Volume (Person/Group) \\
\hline 1. & $\begin{array}{l}\text { Community becomes volunteers/community activator } \\
\text { (PTM) }\end{array}$ & Person & 254 \\
2. & $\begin{array}{l}\text { Community that is attend on the early Socialization } \\
\text { Activities }\end{array}$ & Person & 878 \\
3. & Community that follows the training/coaching & Person & 1,056 \\
\hline
\end{tabular}

Source: Directorate General of Human Settlements of Ministry of Public Works in Establishing of Hopefully Pillar, 2011.

The high community participation levels which are involved in the implementation of NUSSP program policies in the physical construction of roads and drainage included the development of environmental sanitation, the provision of clean water and solid waste facilities, such as community volunteers as community mobilizers (TPM), consisting of 254 people who have function to assist and mobilize the poor communities in their environment in order to participate in the NUSSP's activities. The community participation level can be measured by mentioning the presence indicators in the socialization process, i.e., 878 people in the initial socialization activities of the NUSSP program in their respective regions, while the people who have attended the training by NUSSP management team were 1,056 people. 


\section{Discussion}

\subsection{The Actors' Network Roles in NUSPP's Program Policy Implementation Based on Tridaya}

As an effort to realize the successful implementation of NUSSP program policy in handling urban slum settlement in Makassar city, especially in five urban villages of this research location, it has involved various implementing actors of NUSSP program/activity in stages, from the central level to the urban village's level, from the government and communities in the slum settlement areas. The existence of NUSSP program implementation actors, as stated by Purwanto (2015), it is very necessary presence as a mandated implementing agency to implement a policy. While, Kadji (2015) defines it as an implementing actor who is a policy implementer as a policy of stakeholders or authority parties who have interest with the policies (such as government, private and civil society) that are directly involved in implementing of every public policy product, including NUSSP program policy in handling slum settlements in Makassar City.

Referring to its position, implementing agency or policy of stakeholders as NUSSP's program implementation actors have a crucial role, because the NUSSP's implementing actors will ensure the success of all NUSSP's activities, ranging from planning, implementation, and the supervision. This is relevant to Winarno's (2008) statements, i.e., successes and failures of policies implementation in the field depends on the beliefs among actors involved in the policies implementation by using appropriate techniques or methods based on the situation and character of the policies. Therefore, the role of NUSSP implementing activities actors at all levels has been supported by the capacity of NUSSP implementing organizations in relation to the accuracy of the structure, number and quality of human resources, the support of the environment in which the NSSSP program implementation organization's tasks must be conducted. On the other hand, Aneta (2012) confirms that the roles of government bureaucracy in the effort to succeed implementation of poverty eradication program in urban have strategic position and determine the fluency and sustainability of the program. The roles of government bureaucracy to the urban village level, which has direct access as the responsible, implementer and facilitator, should be able to stimulate the growth of "development creativity and motivating" in society.

When it was analyzed by using the actor network model approach, it was relevant to be implemented in the network of NUSSP's implementing actors in the field and that was integrated with the "from above" implementing actors of Makassar City government (Regional Development Planning Board of Makassar City, the Public Works Department, the Social department, the Education and Culture Department, Health Department, etc.) and private parties. Meanwhile, the "from below" Community Self-Reliance Agency (BKM NUSSP) was conducted through the facilitation and management of the NUSSP and Village Facilitators from the NUSSP program, to succeed the implementation of NUSSP's program policies at the urban village level.

The integration of actors' cooperation network was "from the top" through "top-down" approach and "from below" through the "bottom-up" approach in accordance with the "ACF's" Advocacy Coalition Framework (Sabatier, 1991) which focus on both of bottom-up and top-down networks in the implementation structure of Heclo, Browne and Wildavsky as cited in Parsons (2006). This is asserted by Kadji (2015) which states that in implementing a policy for the public interest, it is necessary to prioritize cooperation networks between stakeholders (government, private, and community) with the spirit of synergy in the principle of symbiotic mutualism, because the government acts as a facilitator, dynamist and development motivator; the private sector as the forcing driver of the public economy; and society as dynamic energy, both as object and subject of government policy and development. In this connection, according to Kadji (2015), in the cooperation network, the public policy implementation must strengthen cooperation network from the government, private, and society as policy of stakeholders.

The involvement of NUSSP executing actors as policy of stakeholders from the government, private and community as well as the role of implementing agency in implementing NUSSP program policy in handling slum settlement in Makassar city can be seen from the cooperation built by Korkot-3 NUSSP management of Makassar city with Makassar city government through a partnership network with the Head of Public Works Office of Makassar City as the head of LCO (local coordinating office) with the role of regional coordinator as well as head of Satker (Work Unit). Similarly, NUSSP executor actors were well established with the Regional Development Planning Board (i.e., known in Indonesian acronym is Bappeda) of Makassar city as the planner and coordinator of development activities in Makassar city. This is similar with the realization of NUSSP implementing partnership which was established as the policy implementation actors at the sub-district and urban village levels, so that the sub-district and urban village governments cooperate with the Facilitator as a companion to the NUSSP activities that were initiated by the collective leaders of the Community Self-Reliance Agency (BKM) at the urban village level. 
Regarding to the cooperation network established between the government's actors with the management/team leader of NUSSP at Makassar city level, it has become the determining factor of success of NUSSP policy implementation in Makassar city. This is confirmed by the arguments as stated by Warden (1992); Howlett and Ramesh (1995) and Nugroho (2009) which affirm that relationships between government actors, the public and the private sector will form a policy network that determines the achievement of the public interest at the implementation stage, intertwined in the interaction of government departments and organizations with the society organizations, in this case, it is referred to the NUSSP's Community Self-Reliance Agency (BKM). Therefore, the level of acceptance and support for NUSSP program policies is quite high from NUSSP executing actors in empowering the poor community in the field. This is relevant from Aneta's (2012) results study which revealed that the high level of acceptance and support of all parties and the community was a determinant factor of successful of program policies implementation for the poor community empowerment in a community that became the target of its program.

Similarly, the cooperation network between NUSSP executing actors at the community level, and the BKM's collective leaders who are accompanied by the Urban Village facilitator (Faskel) in the five urban villages, had been well established with the urban village and sub-district governments and with the social institutions of the community, in order to provide services to poor people in every empowerment activity in their regions. The NUSSP's activities implementing actors at the urban village level that directly provide services to the poor society have the sincerity to carry out the tasks of the poor community empowerment. It was truly confirmed by Abdussamad (2016), who states that every apparatus (actor) provides services to the recipients of the public service with a vengeance that must be performed from the apparatus to serve by giving satisfaction to the customers (poor community) who are served.

Based on this context, each NUSSP's implementing actor at each organization level must have competence in providing public services, both managerial and technical skills in accordance with their respective fields. It was relevant and congruent with the statements stated by Abdussamad (2016), apparatus who have the competence are able to provide the quality services, because they will truly try to be able to carry out their duties and work properly based on the established standards, so they are able to provide good service to the poor citizens in the slum settlement areas.

\subsection{Results Analysis of "Pancadaya" Approach Concept in the Poor Community Empowerment}

Essentially, the concept of "Pancadaya" approach to the poor communityempowerment has two advantages that have accommodated by the cultural and religious dimension compared to the "Tridaya" approach which focuses only on three dimensions, i.e., environmental, social and economic development empowerment (Krismanto, 2003). Therefore, in implementing the NUSSP program policy in the poor community empowerment in Makassar city, by applying the "tridaya" (environmental, social and economic development) empowerment approach, it has not focused on the empowerment aspect which utilizes optimally the religious and cultural values based on local wisdom that grew in the poor communities (i.e., Bugis-Makassar) in the slum settlement areas.

Based on the findings of the importance of the cultural and religious values dimension in order to get attention in empowering the poor community to support the successful implementation of urban slum settlement policies in Makassar city, thus the "tridaya" empowerment approach has occurred a process of developing approaches based on the demands of the poor community's environmental needs and local wisdom, so that an adaptive and accommodative approach, i.e., "Pancadaya" approach is emphasized on the five empowerment dimensions, namely: (1) development of the physical environment; (2) social; (3) the economy; (4) culture; and (5) religion. The concept of "Pancadaya" empowerment approach as one of the findings in this study can be seen in Figure 3. 


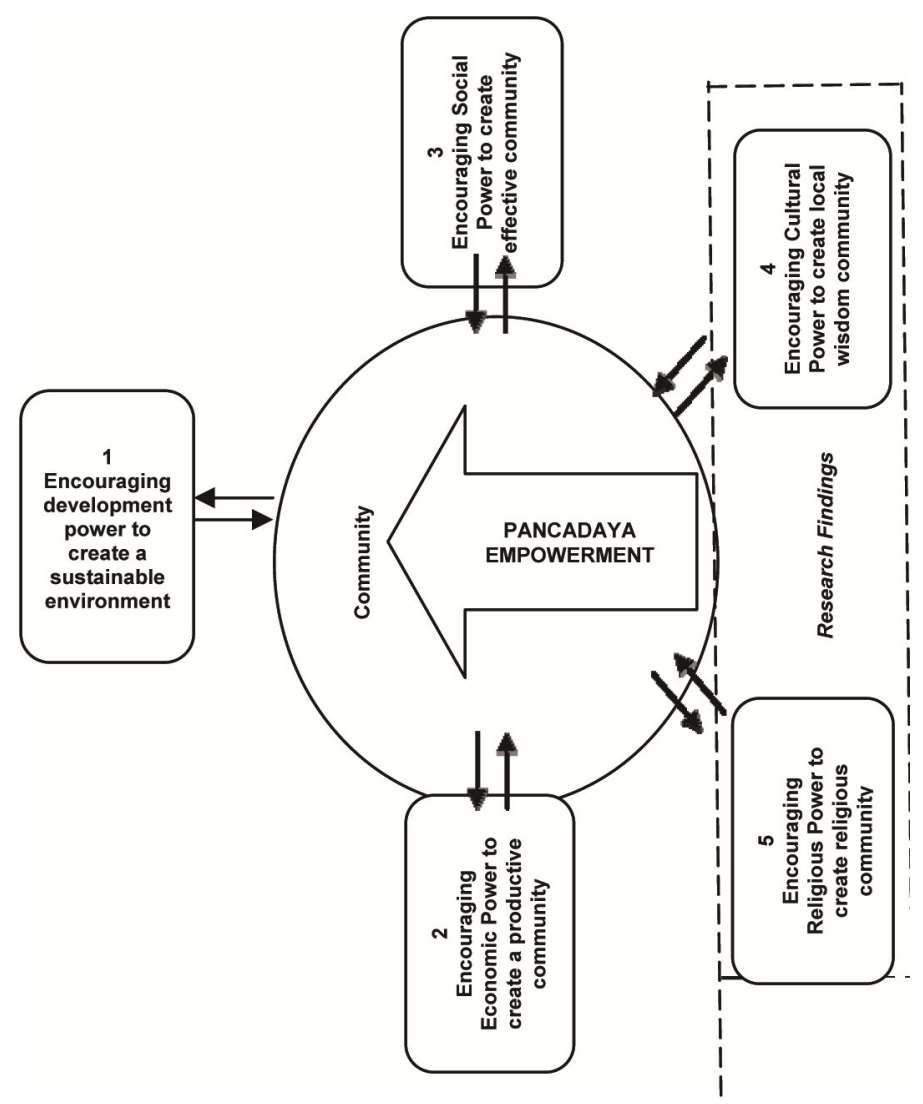

Figure 3. Pancadaya empowerment approach

\subsection{The Strengths of "Pancadaya" Empowernment Approach Concept Based on Local Cultural Values}

The strength of "Pancadaya" empowerment approach is the development of the "Tridaya" approach (Krismanto, 2003) which only focuses on three dimensions, i.e., environmental, social and economic development empowerment. However, the "Pancadaya" approach has accommodated two dimensions, i.e., culture and religious dimension in empowering the poor community.

The urgency of the poor community empowerment in the local wisdom-based cultural dimension is interpreted as the laying of local cultural values that appreciate poverty reduction practices initiated by local actors' level who work together strategically in various sectors of the poverty alleviation (Saharuddin, 2009). As a reinforcement of the importance of local cultural values in traditional practices as a means of implementing this poor community empowerment program, a case study example can be seen from the success of the Mother Rosa Memorial Foundation (MRMF) which is a Catholic charity organization, in implementing empowerment programs through education for poor families in Ugnayang Magasakang San Simon (UMSS) in Pampangan Philippines (Ohama, 1999). Through its holistic understanding of cultural aspects, the "MRMF" in implementing value-added training programs and the formation of organizational leadership and management take on traditional community values and practices as a practical facilitator for implementing the program, namely "Saupan" (participation and collaboration), "Behind Diwa" (reflection to help themselves), and "Damayan" (taking part/sharing and collective responsibility)-serve as their organizational attitude code (Ohama, 1999). By utilizing the original values for self-reliance and collective efforts for all members of the farmer's group is to strengthen their collective activities and sense of identity by applying the local cultural approach that is possessed. It was proven to provide relatively satisfactory results in implementing various management development and management programs for strengthening their organizations and improving their ability to manage collective enterprises that can provide mutual benefits and increase the welfare of farmer group from poor communities in the area.

Efforts to empower poor communities by utilizing local cultural values, as implemented by the NUSSP Coordinator of the Community Self-Reliance Agency (BKM) in the five urban villages of the study sites. The poor community empowerment is packaged in accordance with the characteristics and culture of the community 
based on the local wisdom that develops within the Bugis-Makassar community, as well as "siri" or "siri' Masiri" (shame) values which embodies the Bugis-Makassar to be always willing to change, improve, and develop a better fate; So the value of this culture can be used as a motivation to work hard in achieving an achievement. Therefore, the Bugis-Makassar people still hold the life philosophy of "resopatemmangingnginamalomonaleteipammase Dewata" which means that only hard work with earnest will obtain mercy/blessings from Almighty God (Abdullah, 2015).

In relation to the context of the poor community empowerment based on local wisdom, the concept of "reso" (hard work) becomes a source of motivation and capitalism spirit for Bugis-Makassar community (Umar, 2012). The concept of "reso" as a Bugis-Makassar cultural value can serve to build entrepreneurial spirit of the poor community in order to provide new business or develop informal business and service business based on its level proportionally in slum area of Makassar city. Hence, the Bugis-Makassar cultural values can be used as motivation and spirit in productive economic empowerment for poor people, so that in performing their life, they always work hard and earnest to find sustenance in various kinds of work which provide legal matter, so it does not educate their selves to become a beggar.

The cultural value of Bugis-Makassar which is revealed in the life philosophy of "resopatemmangingngi namalomonaleteipammase Dewata (only by hard work by God will give His grace)" functionally can be used as character formation and hard work attitude of Bugis-Makassar people in the slum settlement areas; Because sometimes there were still a little percentage of poor people mistaken in maintaining their daily lives, by using practical logic on the principle that "it's better to die bloody than to starve", which provides a logical justification for freedom that has no religious character and morality in it in order to sustain life in a state of economic disability, even if it is to commit crime that violates cultural values, religious rules and positive laws, which can create insecurity and discomfort in social life.

When siri" is associated with the "pace" (i.e., Makassar) value or "pesse" (Bugis), it is interpreted as a painful and samrting feeling in the Bugis-Makassar people, when seeing the suffering of others (Abidin, 2006); So they feel ashamed if they do not help those people who are weak, because they feel the same destiny and awkwardness in the society life. Therefore, in the social life, Makassar people still maintain and practice the cultural values of "abbulosibatang" which means that a high sense of solidarity to work together and help each other in solving every life difficulty, and feel the happiness together (Syarif et al., 2016). In the context of the poor community empowerment, this cultural value needs to be actualized in the community life in order to foster a sense of togetherness and sense of mutuality to participate in the region development. The effort to foster participation in Bugis-Makassar community through the "abbulosibatang" (Makassar) spirit which means solidarity; "sipatuosipatokkong" means supporting each other in life; "Mali siparappe" (Bugis) means helping each other in difficulties; it is really relevant to the statements stated by Glen (1993) as cited in Parsons (2006), which revealed that it is important to empower people in the community to participate in planning and fullfillment their needs.

This is similar with the application of Bugis cultural values with the philosophy of "sipakatau" (mutual respect/humanize); "Sipakalebbi" (mutual respect); and "Sipakainge" (remind each other). While in Makassar ethnic community, it is known as "sipakabaji" (mutual forgiving) philosophy and "sikatutui" (mutual reminder), which are utilized by BKM NUSSP Coordinator in five urban village of research locations in order to support the successful implementation of collective-collegial leadership in building communication and coordination between Social institutional leadership elements at village level and other community organizations. It was also included in formal and informal communication interaction and coordination with NUSSP actors at NUSSP Management/Leader level (Korkot NUSSP Makassar City/OC-2 NUSSP/LCO NUSSP/Satker NUSSP of Makassar city), village, and sub-district and SKPD of Makassar city. Similarly, at the level of community (poor) residents who communicate with each other and interact with each other and the BKM NUSSP collective leadership in the field, often practice the cultural values of "sipakatau, sipakalebbi, sipakainge" as a humanist philosophy loaded with appreciation of human values, so it places proportionally the position of the poor citizens who are respected as human beings who have rights and obligations in community life in supporting the implementation of NUSSP activities in their regions.

In accordance with the present context, Bugis cultural values are really relevant to be applied in the effort of empowering the poor community to create an atmosphere of mutual respect for each other in the communication interaction (formal-informal) between the poor communities and NUSSP executing actors, Government, private, and civic organizations, as well as in joint decision making concerning social life. It is also applied these cultural values to remind among poor citizens and perpetrators of community assistance in the implementation of each poor community empowerment program. Implications of "sipakatau, sipakalebbi, sipakainge"cultural values 
practicesare manifested in the creation of a harmony and suitability in the society life in slum settlement areas of Makassar city.

Essentially, the roles of Bugis-Makassar cultural values adopted in the poor community empowerment through the "pancadaya" approach, functionally perform local wisdom cultural values for the characterization and mentality of the poor community to work hard with a great entrepreneurial spirit and mutual cooperation with a solidarity spirit and high participation, and foster interactional relationships among citizens with the basis of mutual respect, mutual honor, help each other with the noble spirit in order to realize the practice of human values in accordance with applicable local cultural values within the local Bugis-Makassar community.

\subsection{The Strengths of "Pancadaya" Empowernment Approach Concept Based on Religious Values}

The strength of this "Pancadaya" empowerment approach has accommodated religious-Islam-values in the practice of the poor community empowerment in urban slum settlement areas. The community empowerment in religious perspective shows the actualization of religious values through strengthening within the scope and important sectors of development to meet the needs of the poor societies, individually and family with a balance between the fulfillment of physical and spiritual welfare and the material and spiritual, in the life order of the mutual social community socializing, personal piety and social piety. Therefore, in the religious perspective that in the practice of community empowerment provides reinforcement on the main empowerment dimensions, namely: spiritual dimension, intellectual dimension, and economic dimension (Matthoriq, 2009).

On the other hand, Suryadias cited in Matthoriq (2009) states that the importance of religious approach in the community empowerment through the path in the unity of intellectuality and spirituality. Similarly, the affirmation of Istiqomah as cited in Matthoriq (2009) states that the efforts of community empowerment can be seen as laying a social order in which human beings fairly and openly can make an effort to manifest the ability and potential possessed by society in fulfilling their material and spiritual needs.

Functionally, the importance of the use of religious values-based religious coaching in community empowerment is confirmed from the research results conducted by Budimansyah (2004) which concluded that the more perfect internalization of Islamic religious values in Muslim entrepreneurs sub-sector food processing industry in West Java, is more aware of themselves to meet the nature arranged by Almighty God through the appearance of good work, by always thinking and trying to find new ways to improve the work quality that has been achieved (have achievement motivation). Similarly, the approach of Catholic Christian doctrine through Catholic charity NGOs of the MRMF provides training on traditional Catholic-based values-building and the establishment of five years of sustainable leadership and organizational management (1973-1977) at Ugnayang Magasakang San Simon (UMSS) in Pampangan Philippines, the farmers in the farmer group achieved remarkable results in the increase in rice production and the repayment of their loans (Ohama, 1999).

The second study argument also further reinforces the thesis which was stated by Max Weber (German sociologist) that there is a very positive influence of Christian-Protestant religion, on the birth of a strong willingness and conviction to build from its adherents, for religious teachings command to work hard, honest, dillignet, frugal, to get wealth or treasure as much as possible. Such doctrine content is called by Weber as the "Protestant Ethic" that greatly influenced the birth of the persistent spirit of persuasion of its adherents, as the "spirit of capitalism". Thus, Weber points out the thesis that "Protestant ethics is one of the most important factors in encouraging the spirit of capitalism that makes them to be advanced and prosper" (Budimansyah, 2004).

The concept of hard work is relevant to the teachings of Islamic ethics that emphasize on the importance of hard work as a noble moral obligation in God's judgment. The Islam teachings greatly glorify those who work hard to look for fortune and not consider the type of work that is rough or not, but it more emphasis on the halalor legal aspect. As the words of Prophet Muhammad SAW narrated by Bukhari which means "By the Essence of which my soul is in His hand, really one of you who took the rope then he/she looked for a bunch of firewood and brought with his/her back then he/she sold it and God filled it with the wood, it is best for him/her than he/she begs for man, whether the man gives him/her or rejects it". Based on the content of this hadits, in fact the Prophet Muhammad SAW greatly exalts his people who earnestly work hard to seek legal fortune, even though the work is rough in the man's perspective, than they seek fortune by begging to fellow human beings, as the Prophet's words which mean "The poor do not go around begging others, then they take a bite or two, or receive one or two dates". The Companions asked, "then what is meant by the poor O Rasulullah?" He replied, the man who has no sufficient possessions, but his condition is not known so he is given alms, and he does not beg for something else (H.R. Muslim) in Budimansyah (2004, pp. 76-78). 
Functionally, the role of religious values which were adopted in the poor community empowerment through the "pancadaya" approach is as a process of learning, fostering, and the practice of religious values for the mentality and morality formation so they are formed as noble morals for the poor society in the slum settlement regions. The religious guidance and religious values can be conducted by involving stakeholders from various groups, such as the government (Ministry of Religious Affairs of Makassarcity); Philanthropic institutions (BAZNAS Makassar, Yayasan Rumah Yatim); Religious social organizations (institutions of Muhamamdiyah, Aisyiah, Nahdatul Ulama); Islamic universities (State/Private); and volunteers from faith-based organizations, which have community-based religious empowerment programs.

\subsection{The Achievement Results of Integarative Implementation of NUSSP Program Policy Based on Tridaya}

Referring to Keban's opinion (2004) which states that the effectiveness level is always associated with whether a result of the implementation obtained is a result that is planned. Therefore, from a system point of view, where policy implementation is the process of transforming inputs (objectives and policy content) into a series of operational actions to achieve the desired outcomes (outputs and outcomes). In this context, the policy implementation function is intended to transform the policy objectives into the forms of operational activities required for the policy to achieve the desired outcomes based on its objectives (Rochyati, 2012). In this regard, Dunn (2000) recommends that to find out the results of policy implementation, it should be monitoring and evaluating policy actions, by focusing on two types of implications, namely: implementation of outputs and impacts. Meanwhile, Keban (2004) states that the purpose of monitoring is to assess the efficiency and effectiveness level of the results of the policy implementation.

The results of physical infrastructure development, such as blocked roads and neighborhood roads, drainage development, public toilet/communal septic tank construction, clean water (general hydrant) and garbage in the form of communal garbage are the community productive assets established through the NUSSP's programs/activities at five urban villages of this study sites that have realized NUSSP program in handling the slum settlement areas.

The implementation results of NUSSP program in the form of paving block road construction in the slum settlement areas of Makassar city have implicated economically and socially so that they can relatively cause the socio-economic change impacts naturally for the poor community life, although at certain limits, they depend on the development and the dynamics and socio-economic environment potential of the concerned slum areas, and they have proven adaptively the theory that the results of physical infrastructure development will be followed by socio-economic change (Effendi, 2007).

The implementation results of the NUSSP program policies based on the poor community empowerment in the economic aspect can be seen from the significant effect of the economic impacts for increasing of area/land prices in the surrounding areas of the improvement of walkways and environmental roads. The significant improvement in area/land prices after the infrastructure development in the slum areas can reach $30 \%-100 \%$ even in Lette urban village, it had increased the price to exceed $100 \%$. In addition, due to the dynamics of social interaction and smoothly transportation in and out of the slum areas, they had also caused on the increasing of entrepreneurship spirit of the poor citizens to provide a business selling and pedicab drivers, motorcycle taxi operators and pedicab motorcycles.

In the productive economic empowerment aspect conducted through NUSSP program with the provision of grant loans for housing improvement and land certification did not realized relatively. There are several factors that affect the unsuccessful implementation of housing micro credit program, namely: (1) less responded by BMT/Koperasi entrusted by the management of National Capital Investment (PMN) Mandiri to the proposed determination of prospective customers coming from the target villages of NUSSP activities proposed by the Experts of Makassar Korkot-3; and (2) the imposition of high interest rates for prospective customers from poor communities who have limited ability economically.

Similarly, poor relatively implemented productive economic empowerment programs which were conducted through the NUSSP/P2KP/PNPM Mandiri programs for urban areas in the form of granting revolving loan funds for small-scale enterprises (informal enterprises) due to bad credit, especially in urban villages of Cambaya and Balang Baru. The inhibiting factors of its failure include, such as: (1) a false societies' perspective of the revolving fund user, which assumes that the fund is a grant fund, so that they are not interested in repaying the loan; (2) ineffective initial survey of the data/information accuracy of the poor societies who are eligible and have the right to obtain business capital assistance by business group (KSM); (3) business capital loan is used for capital as well as for daily food expenses, sometimes it is larger than the capital loan; (4) not consistent with the 
prevailing regulations; and (5) weakness of the poor communities' entrepreneur mentality, responsibility, trust, technical management/administration of business management.

It is similar with the achievement results of NUSSP program implementation in social aspect, it can be seen after the development and improvement of paving block and drainage infrastructure in slum neighborhood of Makassar city that have given a natural social impact that its appearance can be seen and felt by the society, such as the intensity of social interaction through the social relations created between pedicab drivers, motorbike taxi drivers and motorbike riders (Bemtor) with the service users/customers are increasing, because the roads have been good so they can ride tricycles, motorcycles and motorbikes until in front of the community residents, because the streets were not muddy and not flooded as before the road paving blocks construction. In addition, if there were social activities conducted by societies, either individually (such as wedding ceremony, sunnatan, aqiqah, etc.) or organized by groups or community institutions (such as pengajian, feast of independence of RI, youth activities, and community activities, etc.) have generally used paving block streets around their homes and/or are considered strategic for the implementation of such activities using tents, platforms and chairs and other equipment that they install themselves and/or hired at commercial tents service providers.

The social institutional empowerment which is highly beneficial by the community and sustainable until now is the formation of Community Self-Reliance Agency (BKM) and Community Driving Force (TPM) equipped with the Implementing Units consisting of the Environmental Management Unit (i.e., known as UPL), the Financial Management Unit (i.e., known as UPK) and Social Management Unit (i.e., known as UPS) are assisted by a group of people (KSM) at RW/RT level that spearheads all the activities in the field. Besides, the institutional empowerment has been given training in accordance with their needs, in implementing NUSSP program in the field.

On the other hand, the achievements results in the form of output implementation of NUSSP program policies in the tridaya-based poor community empowerment at the slum residential areas of Makassar city were in the field of environmental, economic, and social development. First, output of empowerment policy implementation in the slum environment infrastructure developmentincluded: (1) the construction of walkways and paving block roads; (2) the construction of concrete drainage/rebates; (3) the construction of small wooden bridges; (4) the construction of environmental sanitation (MCK)/Family toilet; (5) procurement of garbage facilities; (6) procurement of clean water (drill/soil wells); (7) procurement of Posyandu; (8) procurement of security post; and (9) electricity service into slum areas from the State Electricity Company. Second, the economic environment aspect produces output in the form of: (1) the poor communities get business capital services; (2) provision of revolving funds; (3) the poor community gets entrepreneurship training; and (4) the poor women/mothers receive skills training/life skills. Third, the social empowerment aspect produces output in the form of: (1) improving of decent housing for the poor communities; (2) free education service; (3) healthy services; and (4) public campaign services resulting from the implementation of NUSSP activities, including changes in clean and healthy life behavior.

When it is reviewed from the implementation achievement results of NUSSP program policies in the empowerment based on tridaya approach, the outputs are in the form of outcomes that provide value for the benefit of Makassar city, especially the local government in five urban villages of the study location. First, empowerment in the development aspect of slum settlement environment has given benefit value in the form of: (1) asset ownership by Makassar city government in the form of walkways and environmental road infrastructure which are blocked by the concrete block, drainage/canal, dekker, environmental sanitation (MCK), electric lighting, and garbage; (2) the construction of decent housing for the slum poor communities; (3) the realization of productive economic improvement for the poor communities through independent business; (4) Increasing the income of the poor communities so they smoothly pay the land and building tax; (5) creation of security and public order in slum settlement areas; and (6) the creation of clean, beautiful, and healthy environment in slum neighborhoods areas. Second, the empowerment of economic aspect gives benefit value in the form of: (1) the realization of productive economic improvement for the poor communities through independent business; (2) the creation of entrepreneurs from the poor societies; (3) increasing the poor communities' income so that they smoothly pay property (PBB) taxes; and (4) improving the life quality of poor women economically. Third, empowerment of social aspect gives benefit values, such as: (1) the realization of clean and healthy lifestyle pattern for slum poor communities; (2) increasing the participation/gotongroyong of the poor communities in development at the slum settlement areas; (3) increasing the life quality of the poor communities socially; (4) the creation of clean, beautiful, and healthy environments in slum neighborhoods; (5) the realization of clean and healthy life pattern for the poor communities; and (6) increasing the participation/gotongroyong of the poor communities in development in slum areas. 
Meanwhile, the achievement results of NUSSP program policy implementation in the tridaya based empowerment are in the form of outcomes that provide value for the benefit of the poor communities. First, the empowerment of slum settlement environment development has given benefit values, such as: 1) increase the land/building prices; (2) the walkways/environment roads are smooth, clean, orderly; (3) rarely puddle/mud/ flooding in rainy season and not dusty during dry season; (4) poor people are motivated to earn a living because the roads are good; (5) easy access for poor children to play around their home environment; (6) easy access for clean water/drinking water; (7) increasing the spirit of poor societies to create mobile security systems in their areas; (8) easy access to social activities (bridal party, sunnatan, Islamic festivals, Independence Day) around the housing environment of the poor communities; and (9) poor communities can enjoy electric lighting in slum settlement areas. Second, the empowerment of economic aspect provides benefits in the form of: (1) increasing income and earning business through independent business; (2) improvement of work motivation and skill enhancement for adolescents; (3) increasing income of poor fishermen; and (4) reducing unemployment of the poor communities. Third, empowerment of social aspect gives benefit value in the form of: (1) relatively have adequate housing and increasing motivation to improve their houses; (2) improvement of motivation to live based on clean and healthy behavior (PHBS); (3) easy accessibility of health checks/posyandu for mothers/poor societies; (4) raising awareness of the importance of education for the poor communities; (5) smoothness/ease of school-aged children and diligently go to school; (6) increasing awareness to follow formal meetings for the poor communities; and (7) raising awareness and productivity of women.

\section{Conclusion}

Overall, it is quite integrative and effective implementation of Neighborhood Shelter Sector Project (NUSSP) program policy for phase I (2005-2009), as the housing and settlement improvement program implemented in urban slum settlement areas to empower the tridaya-based poor community empowerment in Makassar city areas, i.e., on aspects of physical environment development (such as roads/drainage, environmental sanitation, clean water, garbage), social and economic aspects, and integrative by combining top-down and bottom-up approaches involving networks of role-based actors at government, private, and the community as policy of stakeholders or implementing agency.

The implementation model of this integrative NUSSP program policy has been implemented systematically, i.e., organizing, leadership, and control. The top-down NUSSP implementing organizations have applied the performance management based on good governance values - transparency, accountability, fair/reasonable, and responsiveness principles; While at the community level, it has applied participatory management based on the local wisdom values at the level of the NUSSP implementing organization in the community self-reliance agency (BKM) in the five urban village of the research location. The development of an integrative model of NUSSP program policy implementation was influenced and transformed from the integrative approach of policy implementation from Soren C. Winter and Mentality, System, Networking (MSN) model as integrative implementation approach from Yulianto Kadji.

The findings of this research included the empowerment concept of "Pancadaya" as an empowerment approach of the poor communities which emphasizes the importance of encouraging local culture and power in order to realize the local wisdom community; as well as encouraging the power and religious values in order to realize a religious society within a local poor community. This "Pancadaya" approach is the development of the "Tridaya" empowerment model of Krismanto, which focuses only on the encouraging of three dimensions, namely environmental, economic, and social development powers. Hence, the development of an integrative model of NUSSP program implementation in the poor community empowerment based on the "Pancadaya" approach combined two approaches, i.e., top-down and "bottom-down" approaches in policy implementation. As well as emphasizing the empowerment and development community should be holistic (comprehensive) that touches all life aspects of the poor communities as the target group development program. At the same time, they give opportunity for the poor community as the development subject to actively participate in various development and empowerment activities by using the "Pancadaya" approach that is to encourage the environmental, economic, social, cultural and religious development powers.

\section{References}

Abdullah, E. (2015). Mengungkap Rahasia Etos Kerja Orang Bugis. Retrieved February 3, 2017, from $\mathrm{http}: / /$ www.kompasiana.com

Abdussamad, Z. (2016). Kompetensi Aparatdalam Pelayanan Publik (1st ed., Cet. 2). Yogyakarta: Deepublish.

Abidin, S. Z. (2006). Kebijakan Publik. Jakarta: Suara Bebas. 
Aneta, A. (2012). Implementasi Kebijakan Program Penanggulangan Kemiskinan Perkotaan (P2KP) Di Kota Gorontalo. Ilmu Administrasi Publik, 1(1), 54-65.

Asian Development Bank. (2003). Kerjasama ADB-Pemerintah-LSM: Sebuah Kerangka Kegiatanuntuk Tahun 2003-2005. Retrieved November 20, 2016, from https://www.adb.org

Budimansyah, D. (2004). Membangkitkan Karsa Ummat. Bandung: PT. Genesindo.

Dirjen Cipta Karya. (2009). Best Practices: NUSSP Mendorong Keberdayaan Mengatasi Kumuh Pekotaan. Jakarta: NUSSP-Departemen Pekerjaan Umum.

Efendi, J. (2007). Perubahan Kondisi Permukiman Kumuh Perkotaandan Perkembangan Karakteristik Pola Penanganannya. Dissertation of Program Studi Perencanaan Wilayah dan Kota: Institut Tekbologi Bandung.

Kadji, Y. (2015). Formulasidan Implementasikebijakan Publik (Kepemimpinandan Perilaku Birokrasidalam Fakta Realitas). Gorontalo: UNG Press.

Keban, Y. T. (2004). Administrasi Publik: Konsep, Teoridan Isu. Yogyakarta: Gava Media.

Korkot-3 NUSSP Makassar. (2011). Luas Kawasan Kumuh Program NUSSP Kota Makassar Tahun Anggaran 2005-2009. Koordinator Kota-3 OC-II NUSSP Kota Makassar.

Krismanto, I. et al. (2003). Pedoman Umum Proyek Penanggulangan Kemiskinan Di Perkotaan (P2KP): Bersama Membangun Kemandirian, dalam Pengembangan Masyarakat Menuju Perumahandan Permukiman yang Berkelanjutan. Jakarta: Proyek P2KP Direktur Jenderal Perumahandan Permukiman-Departemen Permukimandan Prasarana Wilayah RI.

Matthoriq, M. (2014). Aktualisasi Nilai Islam dalam Pemberdayaan Masyarakat Pesisir (Studipada Masyarakat Bajulmati, Gajahrejo, Kecamatan Gedangan Kabupaten Malang). Jurnal Administrasi Publik, 2(3), 426-432.

Menteri Pekerjaan Umum. (2008). Menuju Pembangunan Perkotaan Bebas Kumuh 2025. Speech-Paper Presented on Seminar Session I at event of Peringatan Hari Habitat Dunia 2008 in Bali, 30 October 2008.

Ohama, Y. (1999). Jica International training for Participatory Local Development (Teories and Practices): Case Study on Granduwa Village/Social Mobilization Programme in Matara Distric. The Government of Japan: Japan Onternational Coorporation Agency, 25 January-25 March 1999, Nagoya, Aichi: Japan.

Parawangi, A. (2011). Implementasi Program Nasional Pemberdayaan Masyarakat (Studi Kasus Pengembangan Infrastruktur Sosial Ekonomi Wilayah Di Kabupaten Bone) (Unpublished dissertation). Makassar: Graduate Program of Hasanuddin University.

Parsons, W. (2006). Public Policy: Pengantar Teori \& Praktik Analisis Kebijakan (W. B. S. Tri, Trans., 1st ed., Cet. 2). Jakarta: Kencana.

Pratikno et al. (2007). Kerjasama Antar Daerah: Kompleksitasdan Tawaran Format Kelembagaan. Yogyakarta: Program S2. PLOD. UGM.

Purwanto, E. A. (2015). Revitalisasi Studi Implementasi Kebijakan Publik. JKAP (Jurnal Kebijakandan Administrasi Publik), 8(2), 41-53.

Rochyati. (2012). Mengenal Implementasi Kebijakan Publik. Retrieved December 23, 2016, from https://unair.ac.id

Saharuddin. (2009). Pemberdayaan Masyarakat Miskin Berkearifan Lokal. Journal of Transdisiplin Sosiologi, Komunikasi, dan Ekologi Manusia, 17-44. Retrieved from http://journal.ipb.ac.id/index.php/sodality/article

Sudarpo, B. et al. (2007). Pedoman Umum Neighborhood Upgrading and Shelter Sector Project (NUSSP): Mendorong Keberdayaan Mengatasi Kumuh Perkotaan (2nd ed.). Jakarta: Departemen Pekerjaan Umum Direktorat Jenderal CiptaKarya.

Syarif, E., Sumarmi, S., Fatchan, A., \& Astina, I. K. (2016). Integrasi Nilai Budaya Etnis Bugis Makassar Dalam Proses Pembelajaran Sebagai Salah Satu Strategi Menghadapi Era Masyarakat Ekonomi Asean (MEA). Journal of Teoridan Praksis Pembelajaran IPS, 1(1), 13-21.

Umar, A. (2012). Kapitalisme Bugis: Etika Bisnis Berbasis Kearifan Lokal. Retrieved January 10, 2017, from http://www.ahmadinumar.com

Winarno, B. (2008). Kebijakan Publik: Teoridan Proses. Jakarta: Med Press. 


\section{Copyrights}

Copyright for this articleis retained by the author(s), with first publication rights granted to the journal.

This is an open-access article distributed under the terms and conditions of the Creative Commons Attribution license (http://creativecommons.org/licenses/by/4.0/). 